\title{
A Study of Illegal Migration Trends and The Pull and Push Factors in Nigeria, 2011 - 2017
}

\author{
Umar Kari, Godwin Malasowe,Ogbu Collins
}

\begin{abstract}
Africa's development is seemingly menaced by turbulent challenges arising from internal political crises and insecurity of various sorts. The complexities of the continent's recent trans-border crises exemplified in illicit drug peddling, contraband smuggling, organ harvesting, human trafficking and slavery have nonetheless heightened this mishap. Worse-off is the trending slavery of fellow Africans along the Mediterranean coast by Libyans and other African accomplices. Hence, this study will take a cursory look into the trend of trans-border migration and the pull and push factors in Nigeria. In order to achieve the main aim of this study, data is be sourced from secondary materials published in the forms of textbooks, newspapers, magazines and other documentary texts. Findings from the study show thatthe migration crisis presents a big challenge for Europe and is steering discussions among the member states on the issue of demographic pressure as the result of the ageing European society, concerns over national identity and migrant integration, and questions regarding the economic impact of migration on the member states, as well as the importance of finding a common asylum policy and sufficiently managing the external borders of the EU. The paper recommends that Industrialization of Africa,skill Acquisition and Human Capital Development will help mitigate the desire to illicitly migrate out of Nigeria.
\end{abstract}

Index Terms - Migration, Slavery, Human Trafficking, Civilization, Mediterranean.

\section{INTRODUCTION}

Highlight Human migration has long been considered an important element of population dynamics which can have significant consequences on both areas of origin and destination. Specifically, migration trends in Africa portray some changing demographic characteristics and challenges. Its main drivers are now diverse and in response to not only domestic challenges within most African states but also a reflection of wider global impulses. The open spaces created by trans-border migration poses new challenges for development, while remittances and return migration have potentials for enhanced development of sending areas (Yaro, 2008).

Thus, even though it is increasingly imperative to establish the connectivity between the motivations for migration and human trafficking, the concomitant outcomes for national development abound. For one, the exploitation and trafficking of men, women and children is a humanitarian

Umar Kari, Department of Sociology,University of Abuja, Nigeria

Godwin Malasowe, Department of Political Science and International Relations, University of Abuja, Nigeria

Ogbu Collins,, Department of Political Science and International Relations, University of Abuja, Nigeria problem of global scale. A recent study estimates that at least 12 million people worldwide are trapped in conditions of forced labour. Around a fifth of these are being exploited as a result of human trafficking (ILO, 2005).

In a spatial sense invariably, employment opportunities and developmental changes have been concentrated in a few areas, especially the cities; the rural areas, which dominate both in terms of population numbers and areal extent, have either undergone little growth or have felt the backwash effects of development elsewhere (Hirschman, 1958; Myrdal, 1957). Hence, encouraged by the need to enhance their livelihood and for better living condition migrants from this perspective often drift from rural to urban areas in response to developmental setbacks.

This paper therefore takes a cursory look at the daunting push and pull factors that have necessitated illegal migration trends across Europe by Nigerians. The essence is to proliferate the extant literatures in this area. It is also a significant attempt to question the close link between trafficking in person and labour migration and how they differ from that of many recent media and policy reports. This is because, most reports as Mahmoud and Trebesch (2010) argued, point to legislation and law enforcement, poor border controls, bribery and corruption, or insufficient education as drivers of human trafficking. These factors certainly exacerbate the trafficking problem, but may not explain it at its core.

The frightening economic and political instability may as well be a push for migration trend. This is because opportunities for job mobility, business ventures, personal leisure/relaxation and greener pastures may be opened outside the frontiers of a nation's domestic boundary. Insecurity and political crises could also pose some sort of challenges and hence the desire to migrate. Other reasons span from trade in illicit businesses like drugs, human part/organs to smuggling of contraband goods and services.

\section{Research Questions}

Arising from the above background, this study thus raises the following research questions:

What are the push and pull factors necessitating illegal migration to Europe from Nigeria?

What are the implications of illegal migration and human trafficking on the Nigerian state?

\section{METHODOLOGY}

This research is a library research. It relies on data and information from secondary sources which include: textbooks, journal articles, newspaper collections and 
gazettes. Data are analyzed in form of content analysis.

\section{CONCEPTUAL/THEORETICAL FRAMEWORK}

Conceptual Framework

\section{Migration}

International migration can be defined as: "The permanent movement of individuals or groups from one place to another. It's a basic fact of human history." (Salaheddine, 2010) migration, both legal and illegal, is becoming an ever more important element in international relations. Furthermore, it is a phenomenon that is closely controlled by national migration policies which establish ad hoc rules and frameworks applicable for foreigners moving into destination countries. According to International Organization for Migration (2015) statistics the world migrant population can be estimated at more than 200 million, of whom $90 \%$ are legal migrants and $10 \%$ are clandestine.

For Oderth (2002), migration has shaped the nature of both receiving and places of origin more than any other phenomenon in human geography. Albeit, the concept has been given various intellectual attentions like most terms in the Social Science, it is nonetheless a deliberate response to societal ills and an attempt to structurally adapt according to human needs and necessities.

Hence, the ability to move from one country to the other which may even be of short distance such as cross-border movement between Nigeria and Niger Republic or Nigeria and Benin Republic is termed migration (Everett, 1969). Migration is undoubtedly inspired by economic opportunity or criminal intentions exemplified in trafficking and smuggling of persons, goods and services.

\section{Illegal Migration}

Central to the understanding of illegal migration flow is the traditional push-pull causes. "Push factor" refers to circumstances at home that repel; examples include famine, drought, low agricultural productivity, unemployment etc. while "pull factor refers to those conditions found elsewhere (abroad) that attract migrants. There are many factors that cause the dependent variable (illegal migration) which are independent variables including push- pull factors.

Illegal immigration is defined according to the United States Immigration Services (2000) as: "Immigration across national borders in a way that violates the immigration law of the destination country. An illegal immigrant is a foreigner who either has illegally crossed an international political border, or a foreigner who has entered a country legally but then overstays his/her visa.'Illegal immigration is not a new phenomenon. Soon after World War II, and continuing through the ' $50 \mathrm{~s}$ and ' $60 \mathrm{~s}$, clandestine immigration to France from Spain and Italy took place alongside with legal migration. Attempts to migrate illegally have always been dangerous, e.g., in similar scenario to what is occurring now in the Mediterranean Sea area, some post-WWII migrants in the Pyrenees perished in the snow trying to cross the mountains.

Nevertheless it is also true that illegal immigration in the last decade has known an incredible expansion, particularly with the emergence of globalization as well as bilateral free trade agreements which emphasize regional disparities. For example, the large gap in economic welfare between North and South Mediterranean countries or between the United States and South American countries generates growth in illegal immigration at a worrying rate. In addition to economic reasons, persecution and ethnic cleansing and other causes like weather-related disasters also result in increased immigration. Meanwhile the consequences of the illegal immigration fluctuate from beneficial to disadvantageous aspects depending upon the situation in both source and destination countries (Salaheddine, 2010).

The causes of illegal migration differ from individual to individual and from community to community. If someone asks, why people migrate out of their origin in favor of places that are not familiar? The reasons will vary with causes found in such diverse factors as ecological pressure, economic incentives, psychological motivation, politics situations etc. Africa has extremely accelerating population growth which influences both for internal and external migration due to the population pressure in connection to this Hance (1971) identified areas suffering from population pressure and some indicators are: poverty, soil deterioration, degradation or outright destruction, Use of excessively steep slopes and other marginal lands, Declining crop yields, Changing crop emphases, Breakdown of the indigenous farming system, Food shortages, hunger, and malnutrition, Land fragmentation, disputes over land, landlessness, bad traditional cultures.

Household decision-making is mostly common for predicting illegal migration in less developed societies like Nigeria because they expect short-term migration, circulation and the common practice of remitting income home. Awareness of different ways in which migration and the flow of remittances bring or fail to achieve benefits of development programs and can provide a new perspective on development difficulties and lead to new direction options. Social, economic and non-economic causes are many and varied within countries that include defeat in war, a desire for material gain or food, the search for political or religious freedom etc. Migration takes place when the benefits of migration are assessed by the migrants' interims of comparative advantages(Mohammed, 2016). The other basic reason for migration is that urban areas in destination area are relatively confers of power and privilege. Hence, people migrate from their home land areas for the demand of better necessities and due to the attractiveness of facilities and concentration of resources in the cities. These facilities and resources pull the migrants to abandon the countryside for the towns legally and illegally.

One can take into account the inefficiencies of markets in many developing settings, eventually placed the push-pull factor. Rather than producing adjustment and equilibrium, migration has spurred the growth of the informal sector as rural origin persons settled, at least temporarily, for wages and employment chances below the hoped for formal sector offering (Michael, 1999). Basically when the information from the departed family or neighbor is relatively better, the migratory movement spreads and many more individuals 
follow for no other reason than the fellow feelings which unite families or friends to leave the original area and there may be an enthusiasm for something new for new tasks to undertake as sentiment which animates many of those who venture to migrate.

In line with the position of Mohammed (2016) who extensively submitted that the main notion of pull and push factor studies refer to the causes of migration in relation to economic imbalance. To expatiate on the causes and consequences of the Pull and Push factors the picture below aptly sums up the conceptual framework for this study accordingly:

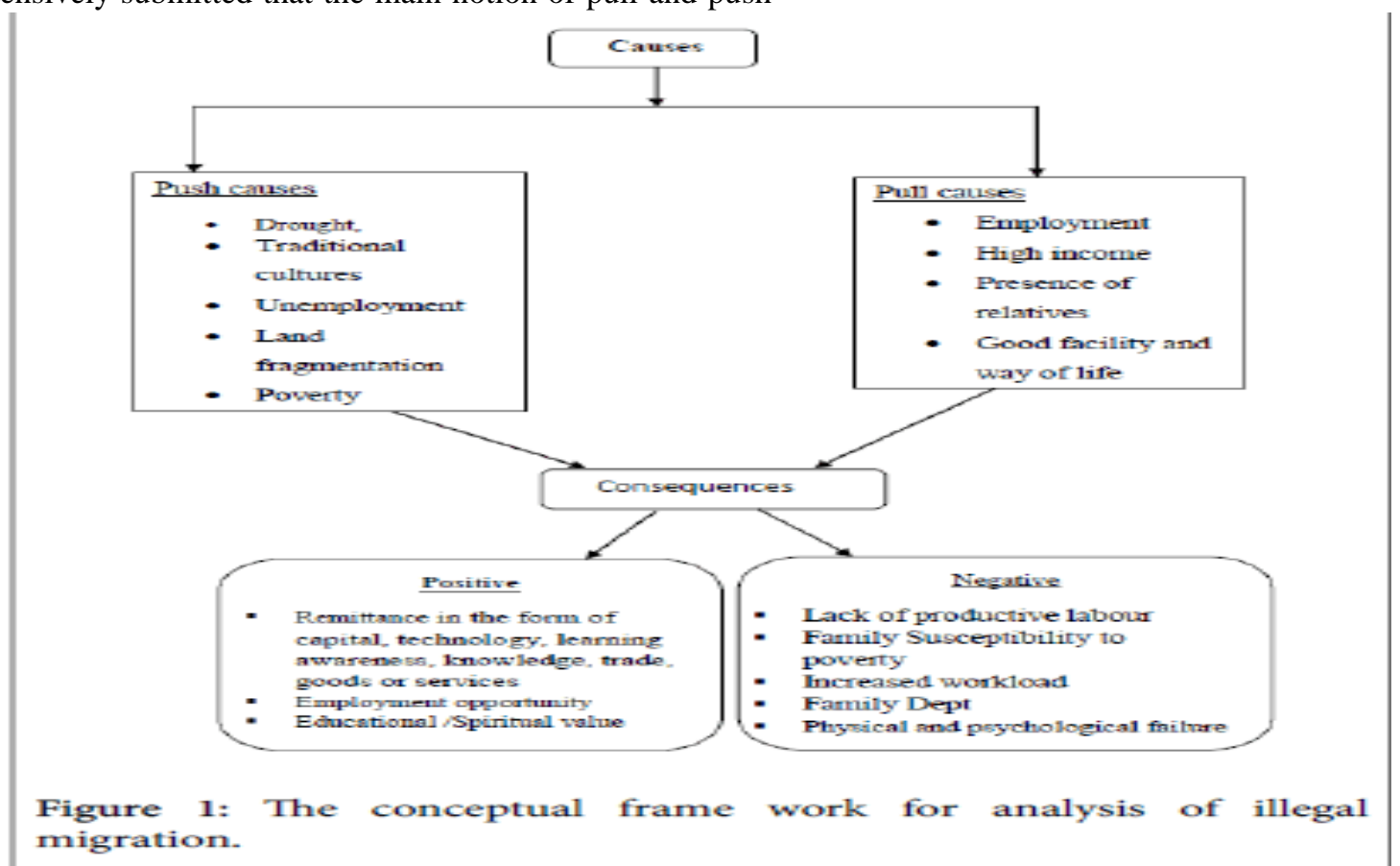

\section{Theoretical Framework}

\section{Neoclassical Theory of Migration}

Neoclassical theory of migration proposes wage differentials as the most important determinant of migration (Lucia, 2011). At present, the dominant theory in explaining causes of migration is the neoclassical theory with its underlying assumption that migration is stimulated primarily by rational economic considerations of relative benefits and costs, mostly financial but also psychological (Todaro and Smith, 2006). The theory has been subjected to criticism on conceptual (Arango, 2000) as well as on empirical grounds (Massey, 1998).

However, owing to its analytical rigor and its ability to propose a set of testable hypotheses and useful tools for analyzing not only the causes but also the effects of migration, it occupies a prominent position in current academic and policy-related research. The propositions of the neoclassical theory of migration were also used (almost exclusively) in the research which preceded the 2004 Eastern enlargement of the EU (Lucia, 2011).

The neoclassical theory understands migration to be driven by differences in returns to labor across markets. The most basic model originally developed to explain migration in the process of economic development in the works of Hicks (1932), Lewis (1954) and Harris and Todaro (1970) highlights that migration results from actual wage differentials across markets or countries that emerge from heterogeneous degrees of labor market tightness.

According to this theory, migration is driven by geographic differences in labor supply and demand and the resulting differentials in wages between labor-rich versus capital-rich countries. The central argument of the neoclassical approach thus concentrates on wages. Under the assumption of full employment, it predicts a linear relationship between wage differentials and migration flows (Bauer and Zimmermann 1999; Massey et al. 1993; Borjas 2008).

Essentially, the impetus for migration and trafficking in persons, illicit drug peddling and smuggling of goods and services are fall-out from poor wages and the obvious need to drift from low income economic environment to high wage labour environments. Although, the drive for more income may not always present itself as the only impulsion for migration, political insecurity, ecological factors, cultural differentiation, xenocentricism amongst others are unarguably causative factors for migration trend. In Nigeria, they no doubt constitute burgeoning justifications for constant exodus to Western Europe, Asia and Northern America. Given this, the theoretical justification for this paper is premised on the neoclassical theory of Migration.

\section{ISSUES AND TRENDS IN ILLEGAL MIGRATION BY NIGERIANS}

\section{Irregular Emigration}

Irregular emigration does occur, despite the associated risks. The estimated total number of nationals abroad varies, as well as the number of nationals apprehended at the border. For example, the former Minister of Foreign Affairs, late Chief Ojo Maduekwe, disclosed the following in a workshop in Abuja, 2008: "Not less than 59,000 Nigerians are currently in Northern African countries without valid travel documents. This number represented those who were in transit waiting for the opportunity to migrate to 
the West. Figures available to the Ministry showed that 8,000 of the illegal immigrants were in Morocco, 16,000 in Algeria, 20,000 in Libya and about 15,000 in Mauritania" (Vanguard, 2017). He also noted that there are increased rates of repatriation of Nigerian migrants from different destinations abroad, especially from the European Union. In addition, the former Minister stated that:

Information provided by our missions abroad indicated that, apart from those held for simple immigration offences, the majority of those in prison are being held for drug-related offences. Reports had it that over 10,000 migrants has died between 1999 and 2002 while trying to cross over from North Africa to Europe. The circumstances of their departure such as using unofficial routes and without proper documentation have made them vulnerable to criminal gangs. These gangs recruit them into all manner of illicit business, with long jail sentences as consequences when they get caught (Vanguard, 2017).

In 2007 alone, almost 6,500 Nigerian citizens were apprehended in the European Union for illegal immigration. This number represents - after Senegal - the largest population among the countries of the ECOWAS region. The large majority of apprehensions were carried out in Italy $(2,523)$ and Spain $(1,243)$. In the same year, 1,422 Nigerian citizens were removed from the European Union. As in the case of apprehensions, removed Nigerians represented the largest number - after Senegal - in the ECOWAS region although the figure had decreased from the 2,113 carried out the previous year (CIREFI, 2009).Internal apprehensions refer to the illegal presence of aliens in the territory of European Union.

\section{Trafficking and Smuggling in Persons}

Trafficking and smuggling in persons from Nigeria has taken varied forms and been on the increase over the years. As very few asylum applications are granted, those denied asylum in some cases stay on illegally, at least for some time. In addition, some minors and women who are granted asylum status run away. In a few cases, the asylum system is being abused by traffickers to get Nigerian women and children trafficked into the European prostitution market. The trafficking network is based on a strong link, involving different categories of actors and contacts at the source, Nigeria, and destinations, mostly countries in southern Europe (Okojie et al., 2003). In 2009, NAPTIP reported that 46 per cent of Nigerian victims of transnational trafficking are children, with the majority of them being girls trafficked for commercial sexual exploitation. Some of the victims are Nigerian, while others are trafficked from other African countries through Lagos. In addition, women, girls and boys are trafficked between Nigeria and other West and Central African countries, primarily Benin, Cameroon, Gabon, the Gambia, Ghana and Niger, for forced labour in homes, on the streets and in quarries. Benin is a primary source country for boys and girls who are trafficked for forced labour in Nigeria's granite quarries. Nigerian women and girls are also trafficked to North Africa, Saudi Arabia and Europe, most notably to Austria, Belgium, Greece, Italy, the Netherlands, Norway and Spain. The Nigerian State of Edo is a primary source area for woman and girls who are trafficked to Italy for sexual exploitation (United States Department of State, 2008). Most of the trafficked women in Europe are believed to be from the State of Edo, with Italy being the most important destination for trafficked persons from Nigeria, followed by the Netherlands, Spain, Germany and Austria (IOM, 2006).

\section{Illegal Emigration Routes}

The official routes for persons leaving Nigeria are most likely the routes taken by the majority of irregular emigrants. The major departure areas of the trafficked persons from Nigeria are Edo, Kano, Kaduna, Calabar and Lagos, through the neighboring border countries and onward to further away destinations. The latter comprise the ECOWAS Member States of Benin, Burkina Faso, Mali and Niger, as well as Chad, through routes along the south-eastern and north-eastern borders to the Central African countries of Cameroon and Gabon and to northern African countries through Mali (UNESCO, 2006; Milborn and Kreutzer, 2008; Kastner, 2007). Those who travel to Europe over land can be on the road for months, or even several years. Migrants going to Central Africa and Europe use the Lagos axis routes, while those bound for southern Europe and northern Africa cross Nigeria and Niger between the States of Sokoto and Borno (Nightingale, 2002).

In general, it can be said that African countries absorb most of the emigration flows though European countries and the United States are preferred, at least by educated people. There have been observed increase in the total number of emigrants leaving the country annually. In 1991, 458,222 people left (NPC, 1991), more recently, the number doubled to $1,147,228$ in 2005 and 2,637,164 in 2008(NIS, 2009) and these have been on increase up to this time as depicted in the table 2 above.

On account of the porosity of Nigeria's border, many irregular immigrants can enter the country through countless ways along the country's land boundary of 4,047 km. However, the major entry and exit routes used by most regular migrants/passengers, as of 1991 (NPC, 1991), were international airports (Lagos, Kano, Port Harcourt and Calabar), the two major seaports (Port Harcourt and Lagos) and about 150 other border posts, including Seme and Idiroko (southwestern border) and Ilela (Sokoto) and Jibia (north-west and north-east border posts). Since then, Abuja International Airport has been opened. According to a survey by the National Agency for the Prohibition of Trafficking in Persons and other Related Matters (NAPTIP, 2005), the major trafficking routes from Nigeria were Edo, Kano, Kaduna, Calabar and Lagos.

From these centres, and from ECOWAS borders, the routes were Benin, Cameroon, Gabon, Niger, Chad, Burkina Faso and Mali. Also, irregular immigrants could use either the Lagos or the Calabar exit axis, travelling by boat or any other vehicular means, either to enter or leave the country for varied purposes (trade/business, pilgrimage, sexual exploitation, domestic work/urban informal sector, begging). Those who use the northern land routes, via the porous borders of the States of Sokoto, Kebbi, Katsina, Kano, Jigawa, Yobe and Borno, are overwhelmingly male traders and farmers, who perceive the border as an imaginary line. 
However, on the issue of migration, Nigeria still remains a strong attractive pole for immigration population. Table below shows an increase in the total number of stock of immigrants over the years for 101,450 in 1963 to 972,126 by 2006 and an estimated 1.1 million in 2007.

Population and migration characteristics of Nigeria as: 1990, 2000 and 2005

\begin{tabular}{|c|c|c|c|c|}
\hline Year & 1990 & 2000 & 2005 & 2010 \\
\hline Estimated total population at mid-year ('000) & 97338 & 124842 & 140879 & 158259 \\
\hline Estimates of international migrants at midyear('000) & 447 & 751 & 972 & 1127 \\
\hline International migrants as a $\%$ of total population & 0.5 & 0.6 & 0.7 & 0.7 \\
\hline
\end{tabular}

\begin{tabular}{|c|c|c|c|}
\hline Year & 1995-2000 & $2000-2005$ & $2005-2010$ \\
\hline Net number of international migrants ('000) & -19 & -34 & -60 \\
\hline Net migration rate (per 1000 people) & -0.2 & -0.3 & -0.4 \\
\hline
\end{tabular}

Source: UNPD, 2008 and 2010

\section{Government Policies towards Migration}

For a long time, the Nigerian government maintained a laissez faire attitude towards migration. This was apparent in both the 1988 and 2004 National policy on population which made casual reference to migration. The 2004 National policy on population for example mentioned that the Ministry of internal Affairs collect data on international migration and transmit them to the National Population Commission for analysis, but this is the only reference to migration. However, in 2005, the government of Nigeria through the office of the special assistant to the president on migration and human affairs solicited IOM's support in developing a national migration policy. For this purpose in 2006, an inter-ministerial committee comprising relevant government ministries following the senators, agencies and departments was established to produce a home-grown policy that would address the multi-faceted issue of migration. In April, 2007, the national stake-holders conference was organized to present the draft policy with a view to its finalization (NAPTIP, 2005).

The document was subsequently forwarded to the federal executive council for approval but frequent change in government has hampered its swift approval. However, presidential directive by President Yar Adua issued in 2009 mandating the NCFR to coordinate matters relating to migration and internally displaced persons in Nigeria, the commission is revisiting the policy. The issue in the draft policy of migration include: Migration and development, Migration and cross cutting social issues, National Security and irregular movement, Forced Displacement, The Human Rights of Migrants, Organized Labour, Internal Migration, National Population, Migration Data and Statistics, and Findings for Migration Management. In addition, the draft proposes the establishment of an agent or commission to coordinate the different management aspects of the migration policy among others (NAPTIP, 2005).

Notwithstanding, there are other programmes currently in Nigeria that are related to Migration and development. One of these is the Joint Migration and Development Initiative (JMDI) which is implemented in Nigeria by the UNDP. The overall objective of the JMDI is the joint is to support civil society organizations and local authorities in harnessing the benefits of migration and development. JMDI aims to set and reinforce network of actors working on migration and development identifying good practice this field and share this information with practitioner and policy makers with a view to feeding into policy making on migration and development. Also the United Nations Office on Drug and Crime (UNODC) is currently implementing three projects in the area of human trafficking and smuggling. The preventing and combating trafficking of minors and young women from Nigeria to Italy project aims at addressing the issue of minors and young women trafficked from Nigeria to Italy for sexual exploitation, by creating on the one hand, conditions that decrease the vulnerability of women and children to trafficking and on the other hand by strengthening the anti-trafficking capacities of the Nigeria government.

\section{IMPLICATIONS OF ILLEGAL MIGRATION ON EUROPE AND NIGERIA}

On the Economy: Economically speaking, illegal immigration may have both negative and positive impacts in both destination and sources countries. On the one hand, some specialists argue that illegal immigrants reduce the number of unemployed in the departure countries while increasing that rate in the host countries. A specific study of the Organization for Economic Cooperation and Development mentions that: "Despite no obvious relationship between immigration and unemployment, concerns are often expressed that immigration will lead to higher unemployment... These concerns are especially evident in many European countries, where unemployment rates are higher."

On the other hand, some researchers assert that illegal immigrants take the jobs that legal residents refuse. Menial jobs that Nigerians have taken range from domestic/industrial cleanings, mortuary attendants, security watch, to professional jobs especially in the area of medicare as indicated in the pull factors above. Economically, this has reduced the amount of those needed in the informal (SME sectors) which is often the life wire of developing economies.

On Demographic Pressure: Demographic pressure arising from illegal migration trends by Nigerians to Europe is increasingly unbecoming. The migration crisis presents a big challenge for Europe and is steering discussions among the member states on the issue of demographic pressure as the result of the ageing European society, concerns over national identity and migrant integration, and questions regarding the economic impact of migration on the member states, as well 
as the importance of finding a common asylum policy and sufficiently managing the external borders of the EU. Europe is facing the worrying demographic trend of an ageing and shrinking population. The EU's total fertility rate is not much more than 1.5 children per woman. According to The 2015 Ageing Report of the European Commission, the population of the EU member states will reach 523 million in 2060, with the working-age population (15-64 years old) falling to just 202 million (European Commission 2015c).

As the EU's working-age population will decrease by 17.5 million (European Commission 2015a) in the next decade, there will be a high dependency ratio, most probably resulting in reduced pension and welfare systems and a scarcity of labour by 2035 (International Migration Institute and University of Oxford 2011). Germany, for example, having the oldest population of all countries in Europe, is facing increased labour demands, as jobs in the country are being created so fast that the native society is unable to fill them. In the long term, migration could significantly contribute to maintaining the sustainability of the welfare system and ensuring the sustainable growth of the EU economy by filling niches in both the fast-growing and the declining sectors of the economy.

However, legal migration can only drive the above goal as against the litanies of pressure the demography of Europe is receiving as a result of illegal migration. In fact, The Deputy Head of European Union (EU) Delegation in Nigeria, Mr. Richard Young, has repeatedly expressed concerns over the increasing number of illegal migrants from Nigeria to Europe. Yet, many of those people are merely compounding their miseries because what await them on the other shores are no longer opportunities but detention, most often under subhuman conditions. In urging Nigeria to grow its economy and tackle the challenge of poverty, Young also warned that if the immigration issue was not addressed, it might have long term impact on the EU-Nigerian relations (ThisDay, 2017).

On Human Resource/Capacity Development: No doubt, incoming educated migrants are assets with regard to the future European labour market (European Parliament, 2015). To a large extent the future of economic growth in the EU will depend on whether young migrants arriving in Europe possess the skills needed to contribute to the efficiency of European labour markets compared to the native population. More highly educated migrants could affect the labour market outcomes for native workers as they could have an adverse effect on the wage and employment levels of existing workers and affect the labour supply (Aiyar et al. 2016a).

Additionally, the level of education and the labour status of the migrants in their countries of origin is often a decisive factor when seeking further employment in the European labour market. However, even highly skilled migrants often face discrimination, as a large number of migrants with higher education qualifications experience professional downgrading after entering the European labour market; this is the result of a lack of recognition of qualifications from third countries and the poor transferability of professional experience (European Research Area 2013).

Less-educated low-skilled migrant workers may increase pressure on public services such as health care, housing and education systems, and this poses a risk of depression in public wages and increased unemployment (Ellyatt, 2015). Low-skilled migrants are willing to work for lower wages than native workers and thus this puts downward pressure on wages, temporarily lowering the wages of incumbents and reducing the capital-labour ratio. Such migrants also create a less favourable net fiscal position because as households they contribute less in taxes and social security (Dadush, 2014).

On Mortality Rate: Illegal migration has in recent times, proliferated the mortality rates of victims involved. So many die because they may get their vital organs harvested; they may also get drown, kidnapped for rituals, sexually abused or murdered aimlessly. Independent Newspapers in an online report (2017) specifically submitted that:

towards the end of last year, Nigerian women, totaling 26, whose ages range from 14 to 18 were reportedly found dead recently in a Spanish warship as they tried to cross the Mediterranean Sea. According to British Broadcasting Corporation (BBC) that made the disclosure, the deceased might have been sexually abused and murdered. It was reported that following several rescues, corpses of the Nigerian women were discovered in a refrigerated section of the Spanish warship, Cantabria, which was also carrying 375 migrants most of whom were sub-Saharam Africans from Nigeria, The Gambia, Ghana, Sudan and Senegal...It is unfortunate that another group of young Nigerians who were promising future mothers, have lost their precious lives under such a tragic circumstance. This was clearly in an attempt to cross the Mediterranean Sea where they erroneously believed lies the so-called greener pasture. The recurring tragedy arising from the rising spate of risky illegal journeys by Nigerians desperately fleeing the country has become worrisome and should be of major concern to the Federal and State Governments.

The dangers of illegal migration by Nigerians to Europe and other countries are unquantifiable. For instance, such as in this particular case, women among the illegal migrants have been sexually abused and murdered by those described as people-smuggling gangs that charge each migrant about $\$ 6,000$ to get to Italy. There have been cases of those left to drown while some are still missing several years after travelling out of Nigeria. The incalculable dangers Nigerians migrating illegally abroad expose themselves to are not only avoidable but also do not worth the risks involved.

On National Security: The crisis of illegal migration has exposed the ruthless human trafficking, smuggling and criminal cartels that profit on the hopes and dreams of young people. Many of these unscrupulous groups are organized by Nigerians (Vanguard News, 2017). It has rubbed off on the future of hapless Nigerians and has nonetheless attracted global concern especially about the face of the Nigerian National Security.

Nigerian Senate President in an interview with Vanguard News (2017) aptly albeit sadly noted that...

As you know, human trafficking and illegal migration are the EU's number one issue with Nigeria. The European Union members fear these issues fuel the attraction of many 
citizens to the divisive messages espoused by ultra nationalist political parties.

Saraki lamented that thousands of young Nigerians continued to risk their lives unnecessarily as they attempt to transit across the Sahara desert and the Mediterranean Sea on the false promise of a better life in Europe and beyond. Unfortunately, this has caused some in the international community and media to shine negative attention on Nigeria, in this respect, the human trafficking and illegal migration crisis has become a national security issue (Vanguard News, 2017).

\section{PANACEA TO ILLEGAL MIGRATION}

Given the above discourse on illegal migration in Nigeria, the research makes the following recommendations:

1. The reintegration of returnees from domestic work in the Arab Middle East countries needs to be comprehensive and sustainable, enabling the returnees to support themselves and their families and avoid the risk of re-migration

2. Another step that can be taken to maximize the positive effects of migration and minimize its negatives is to enhance further regulation of illegal migration and protect vulnerable groups (internally displaced Persons). Serious penalty should be imposed on those involved in irregular migration and more importantly, stiff punishment for those involved in trafficking and if possible, a life imprisonment sentence for offenders.

3. Government should make deliberate efforts to create more employment opportunities in Nigeria. A large percentage of the reasons for migration are occasioned by economic incentives-a quest for better life. Development in Nigeria has been negatively affected by increasing "brain drain" and loss of labour and manpower via international emigration because of scarce opportunities in the country. The poverty level is very high with the average Nigerian living below the international poverty line while the labour force increases ten folds relative to the available employment opportunities and this force thousands of Nigerians to emigrate yearly. If the government can make a deliberate attempt at improving investment, encouraging FDIs and increase its spending to create opportunities, loss of labour will be greatly minimized.

4. The government should realize the strategic importance of migration in development, hence, it should give its full support to formalize and implement the national policy on migration. The development of a comprehensive migration profile would be essential for migration management.

\section{CONCLUSION}

It is conclusion of this work that the government of Nigeria should expand its horizon beyond just management of international migration but also focus almost equally on internal migration since it's a precursor for international migration and occurs on a relatively greater scale and it is vital for understanding the level of development of a country. Government can achieve this by ensuring equitable distribution of income in the economy. This can be done by making a deliberate attempt at tackling the issue of economic dualism by improving investment in the less developed sectors of the economy to promote industrialization in these sectors and discourage uneven development. The government can also help out by addressing the current insecurity problems in the country manifesting in the forms of herders/farmers hostilities, Boko Haram terrorism amongst others.

In recent years, a large proportion of the total internal and external migration experienced in the country has been occasioned by the incessant insecurity challenges prevalent in the northern part of the country. Many non-northerners have fled the north and this has led to a drastic collapse in the economy of the north which is the most populated part of the country, hence affecting development negatively. The government should make a deliberate attempt at eliminating the insecurity problems in the north and should consciously sue for an all inclusive government.

\section{REFERENCES}

[1] Aiyar, S., Bergljot, B., Nicoletta, B., Helge, B., Enrica, D., Allan, D. Christian, E., Huidan, L.

[2] Arango, Joachim. 2000. "Explaining migration: a critical view." International Social Science Journal 52 (165): 283-296.

[3] Bauer, Thomas and Klaus F. Zimmermann. 1999. "Assessment of possible migration pressure and its labor market impact following EU enlargement to Central and Eastern Europe." A study for the Department of Education and Employment, UK. IZA Research Report No.3, July.

[4] Borjas, George J. 2008. Labor Economics. Fourth Edition. McGraw-Hill International/Irwin.

[5] Commission for the 16th Permanent Representative Committee and the 13th Ordinary Session of the Executive Council, June 2008.

[6] Dadush, U. (2014). The effect of low-skilled labour migration on the host economy.Global Knowledge Partnership on Migration and Development Working Paper. April.

[7] Ehrhart, H., Le Goff, M., Rocher, E., \& Jan Singh, R. (2014). Does migration fosterexports? Evidence from Africa. World Bank Policy Research Working Paper no. 6739.

[8] Ellyatt, H. (2015). Four reasons why Europe's migrant crisis matters $C N B C, 14$ September.

[9] European Commission. (2015a). A European agenda on migration. Communication (2015), 240 final, 13 May.

[10] European Commission. (2015b). Common European Asylum System.

[11] European Commission. (2015c). The 2015 ageing report.

[12] European Commission. (2016). European agenda on migration.

[13] European Parliament. (2015). Economic challenges and prospects of the refugee influx.

[14] European Research Area. (2013). African migrants at work: Labour market integration in Europe \& re-integration of returnees. MAFE Project Policy Briefing no. 4.

[15] Hance WA (1971) Population migration and urbanization in Africa. Colombia University Press, New York.

[16] Hicks, J.R. 1932. The Theory of Wages. London: Macmillan.

[17] Hirschman, A. 0. (1958) The Strategy of Economic Development. New Haven: Yale.

[18] ILO (2005). A Global Alliance against Forced Labour. ILO, Geneva.

[19] Independent Newspapers (2017) Dangers Of Illegal Migration By Nigerians, November 13

[20] International Migration Institute \& University of Oxford. (2011) Exploring the future of migration in Europe. IMI Policy Briefing no. 8 July.

[21] International Organization for Migration (IOM) Migration in Nigeria; a country profile 2009

[22] International Organization for Migration. (2016). 2030 agenda for sustainable development. 
[23] International Organization for Migration: 2006 Migration, Human Smuggling and Trafficking from Nigeria to Europe. Migration Research Series No. 23. IOM, Geneva.

[24] Lewis, W Arthur. 1954. "Economic development with unlimited supplies of labor", The

[25] Linda, K., Sebastian, S., Antonio, S., \& Petia, T. (2016a). The refugee surge in Europe: Economic challenges. International Monetary Fund

[26] Lucia Kurekova (2011) Theories of migration: Conceptual review and empirical testing in the context of the EU East-West flows being a Paper prepared for Interdisciplinary conference on Migration. Economic Change, Social Challenge. April 6-9, 2011, University College London

[27] Mahmoud T. O. and Christoph T. (2010) The Economics of Human Trafficking and Labour Migration: Micro-Evidence from Eastern Europe, 3rd IZA/World Bank Conference on Employment and Development in Rabat and the Annual Conference of the European Society for Population Economics in Sevilla

[28] Manchester School of Economic and Social Studies 22: 139-191.

[29] Massey, D. S., Arango, J., Hugo, G., Kouaouci, A., Pellegrino, A., Taylor, J.E. (1998). Worlds in motion. Understanding international migration at the end of the millennium. Clarendon Press Oxford.

[30] Massey, Douglass S., Arango, J., Hugo, G., Kouaci, A., Pellegrino, A., Taylor, J.E. (1993). "Theories of international migration: a review and appraisal," Population and Development Review 19 (3): 431-466.

[31] Micheal JW (1999)_Migration, Urbanization and Social Adjustment. Brown University, US.

[32] Mohammed YA (2016) Cause and Consequence of Cross Border Illegal Migration from South Wollo, Ethiopia. Arts Social Sci J

[33] Mydral, G. (1957). Economic Theory and Underdeveloped Regions. London: Duckworth. University Press

[34] National Bureau of Statistics (NBS) 2008 Trade Statistical News. Abuja

[35] National Commission for Refugees (NCFR) 2008 Update on Refugees, Returnees and Internally Displaced Persons in Nigeria. Report submitted by the NCFR. The African Union

[36] Nigeria Immigration Service (NIS) 2009 Information provided by an NIS representative participating in the technical working group established under the National Migration

[37] Okojie, C. et al. 2003 Report of a Field Survey in Edo State, Nigeria. United Nations Interregional Crime and Justice Research Institute, Programme of Action against Trafficking in Minors and Young Women from Nigeria into Italy for the Purpose of Sexual Exploitation.

[38] Profile Project, Nigeria.

[39] Ruth Gursch - Adam and Lívia Benková (2016) The impact of demographic developments in Africa on Europe European View (2016) 15:291-304

[40] ThisDay (2017) On Nigeria's Migration Problem, October 3

[41] Todaro, M. P. (1969). "A model of labor migration and urban unemployment in less-developed countries," American Economic Review 59:138-148.

[42] Todaro, M. P. and Steven Smith. (2006). Economic Development. Boston: Addison Wesley.

[43] UNESCO (2006) Human Trafficking in Nigeria: Root Causes and Recommendations POLICY PAPER SHS/CCT/2006/PI/H/2 Policy Paper Poverty Series n ${ }^{\circ} 14.2$ (E) Paris 2006

[44] Vanguard News (2017) Human trafficking, Illegal migration, threat to national security, November, 20

[45] Yaro, A. J. (2008) Migration in West Africa: Patterns, Issues and Challenges Centre for Migration Studies University of Ghana, Legon. 